\title{
Ana Dili Olarak Arapça Konuşan Öğrencilere Türkçenin Yabancı Dil Olarak Öğretiminde Yalancı Eşdeğer Kelimelerin Rolü
}

\author{
Ömer ÇIFTÇI' \&Rıdvan DEMIRCI ${ }^{2}$
}

\section{Özet}

Tarihsel süreçte çok yoğun bir etkileşim içinde bulunan Türkler ve Araplar birbirlerini dil konusunda da etkilemiş, kelime alışverişinde bulunmuşlardır. Bu durum neticesinde iki dilde telaffuzları aynı olan yüzlerce ortak (ödünç) kelime bulunmaktadır. Bu kelimelerden bir kısmı " kitap, kalem, hürriyet, din, sabah vb." örneklerinde olduğu gibi her iki dilde de aynı anlamda kullanılmaktayken bir kısmı ise " hala, fakat, fen, ustura, nar vb." anlam bakımından çeşitli farklılıklar göstermektedir.

İki dil arasındaki ortak kelimelerin çokluğu, Türkçe öğrenmek isteyen ve ana dili Arapça olan öğrencilerin işini kolaylaştırmakla birlikte çeşitli sorunlara da neden olabilmektedir. Çünkü bu kelimelerden bir kısmı zaman içerisinde çeşitli sebeplerle anlam değişimine uğrayarak iki dil arasında yalancı eşdeğerlikler oluşturmuştur. Ana dili Arapça olan öğrenciler bu türden kelimelerle karşılaştıklarında kelimeleri Arapçadaki anlam ve bağlamında kullanma eğilimi göstermekte, yazılı ve sözlü anlatımda ciddi hatalar yapmaktadırlar. Bu türden kelimelerin öğrenme-öğretme sürecinin başında bilinmesi, öğrenenin ana dilinden yapacağı olumsuz aktarımların önüne geçilebilmesi adına önem arz etmektedir.

$\mathrm{Bu}$ çalışma nitel araştırma yöntemine göre düzenlenmiş ve nitel veri toplama tekniklerinden yapılandırılmış görüşsme kullanılmıştır. Araştırmanın çalışma grubunu, Van YYÜ TÖMER'de yabancı dil olarak Türkçe öğrenen ve ana dili Arapça olan öğrenciler oluşturmaktadır. Araştırmada toplanan veriler içerik analizi aracıllğıyla çözümlenmiş ve elde edilen bulgulardan hareketle yalancı eşdeğer kelimelerin Türkçe öğrenimine etkisi ve ana dili Arapça olan öğrencilerin Türkçe öğrenirken karşılaştıkları yalancı eşdeğer kelimelerden kaynaklı sorunların hangi boyutlarda olduğu tespit edilmeye çalışılmıştır.

Anahtar kelimeler: Türkçe, Arapça, kelime ödünçlemesi, yalancı eşdeğer kelimeler, Araplara Türkçe öğretimi.

\section{The Role of False Equivalent Words in Teaching Turkish as a Foreign Language to Arabic Speaking Students as Mother Tongue}

\begin{abstract}
The Turks and Arabs, who intensively interacted in historical process, affected each other on language and had dealings for word. As a result of this condition, in both languages, there has been common (loan) words with the same pronunciation. While some part of these words is used in the same meaning in both languages like "book, pencil, independence, religion, morning, etc.", some part shows various differences in terms of meaning like "still, but, science, razor, pomegranate, etc.".

Although abundance of the common words between two languages makes the Arabs' work easier who want to learn Turkish, it also causes various problems. Because, some part of these words formed false equivalences between two languages by undergoing meaning change with various reasons in time and the students whose mother tongue is Arabic tend to use the words in Arabic meaning and scope and make serious mistakes in written and verbal lecture when they encounter with such words. Knowing such words at the start of learning-teaching process has importance for averting the negative transfers that the learner will make from the native language.

This study was arranged according to the qualitative research method and interview configured from the qualitative data collection methods was used. The Arabian citizen students learning Turkish as a foreign language in Van YYU TOMER constitute study group of the research. The data collected in the research were analyzed by way of the content analysis and it was tried to determine the effect of the false equivalent words to the Turkish learning and the extent of the problems arising from the false equivalent words faced by the Arabic learners while learning Turkish with reference to the findings obtained.
\end{abstract}

Keywords: Turkish, Arabic, word borrowing, false equivalent words, Turkish teaching to Arabs

1 Doç. Dr., Yüzüncü Y1l Üniversitesi Eğitim Fakültesi, Türkçe Eğitimi Bölümü, omerciftci@yyu.edu.tr

${ }^{2}$ Bilim Uzmanı/Öğretmen, MEB , bau_konsey_25@hotmail.com 


\section{Giriş}

Bir milletin ortak malı olan, o milletin bütün fertlerinin ortak çaba ve gayretleri sonucu vücut bulan ve o milletin varlığının, varlığını sürdürmekte olduğunun en önemli delili konumundaki bir olgu olarak tanımlayabileceğimiz dil, insanlar için hayati bir önem arz etmektedir. Zira Fromkin vd. (2007) de üzerinde yaşadığımız dünyanın dillerin dünyası olduğunu ifade etmekte ve bu hususta özetle şunları söylemektedirler:

“ Insanlar bir araya geldiklerinde ne yaparlarsa yapsinlar -ister oynasinlar, ister kavga etsinler, ister muhabbet etsinler veya otomobil üretiyor olsunlar- sürekli konuşurlar. Arkadaşlarımızla, meslektaşlarımızla, eşimizle, ögretmenlerimizle, annemiz ve babamızla konuşuruz. Otobüs şoförleriyle ve hiç tanımadı̆̆ımı kişilerle konuşuruz. Yüz yüze ya da telefonla konuşuruz. Televizyon ve radyo ile sözcükler sel olur... Yaşamamızın uyanık geçen her anında söz vardır, öyle ki rüyalarımızda bile konuşuruz, ya da bizimle konuşurlar. Bizleri hayvanlardan ayıran en önemli özellik, dile sahip olmamızdır" ( Fromkin vd. 2007:3).

İnsan için bu kadar yaşamsal öneme sahip olan dil, insanoğluyla birlikte dünyanın değişik bölgelerine yayılmış ve çeşitlenmiştir. Dünya üzerinde binlerce farklı dilin konuşulması, insanlar ve toplumlar arasındaki farklılaşmanın temelini oluşturmuştur ( İnan, 2013:9). Bu farklılaşma neticesinde çevresiyle iletişim kurma ihtiyacı içinde olan insanın, kendisinden farklı bir dili konuşan diğer türdeşleriyle de iletişime geçmesi, diller arasında bir etkileşim sürecini başlatmıştır. Bu etkileşim dilin doğasında var olan, tarihin ilk dönemlerinde başlamış, günümüze kadar devam etmiş ve insanoğlu var oldukça da devam edecek bir süreçtir. Bu etkileşimin birçok farklı sebebi olmakla birlikte genel manada dini, ticari, siyasi, askeri ve kültürel sebepler bu süreçte belirleyici olmuştur. Durmuş (2004:2) da diller arasındaki kelime alışverişinin birçok sebebinin olduğunu ifade etmekte ve bunlardan bazılarını şöyle siralamaktadir:

$\begin{array}{ll}\checkmark & \text { "Sosyal hayattaki köklü değişiklikler } \\ \checkmark & \text { Din ve medeniyet dairesindeki değişiklikler } \\ \checkmark & \text { Tercüme faaliyetleri } \\ \checkmark & \text { Alfabe değişiklikleri } \\ \checkmark & \text { Geri kalmışlık } \\ \checkmark & \text { Dil bilinci eksikliği } \\ \checkmark & \text { Çok coğrafya değiştirmek } \\ \checkmark & \text { Dilin türetme yapısının klsırlı̆̆ } \\ \checkmark & \text { Bilimsel ve teknolojik yenilikler } \\ \checkmark & \text { Özenti-kişilerin beğenilme arzusu.”(Durmuş, 2004:2). }\end{array}$

Diller arasındaki bu etkileşimin neticesinde bir dilden başka bir dile transfer edilen bu kelimelerden bir kısmı, kaynak dildeki anlamını korurken bir kısmı da çeşitli sebeplerle anlam 
değişmesine uğrayarak iki dil arasında yazılış ve söylenişleri aynı olan fakat anlam bakımından çeşitli farklılıklar arz eden yalancı eşdeğer kelimelerin ortaya çıkmasına neden olmuştur.

Yalancı eşdeğer, kaynak dildeki bir kelimenin hedef dildeki bir kelimeyle yazılışlarının ve okunuşlarının aynı, anlamlarının farklı olması durumudur (Direkçi ve Gülmez, 2012: 133). Alkan (2012), yalancı eşdeğerliğin görünüşçe aynı anlamca farklı kelimelerden oluştuğunu belirterek, söz konusu kavramın alan yazında "sahte karşılıklar, tam yalancı eşdeğer kelimeler, sözde denkteşler, sahte tanış, biçimdeş sözcükler, yalancı eşteş, biçimsel eşteş sözcükler, yalancı eşdeğerlik, yanıltıcı eşteş, yanlış arkadaş ve aldatıcı kelimeler" gibi başka terimlerle de karşılandığını eklemektedir.

Yalancı eşdeğer kavramı, ilgili alan yazında araştırmacılar tarafından "tam ve kısmî yalancı eşdeğer" olmak üzere ikiye ayrılmaktadır. Güngör'ün (2017) de ifade ettiği gibi yalancı eşdeğerliğin alt gruplara ayrılmasında ise lehçe veya dillerdeki kavram alanlarının örtüşme oranı esas alınmıştır. Kavram alanları hiç örtüşmeyen kelimeler için “ tam yalancı eşdeğerler”, kısmen örtüşen kelimeler için ise "kısmî yalancı eşdeğerler" terimi tercih edilmiştir.

Dünya dilleri arasında kelime alışverişinin yaşanması gibi bu diller arasında yalancı eşdeğerlerin oluşması da doğaldır. Başar ve Çoşgun (2015) konuyla alakalı bir çalışmalarında bu hususta özetle şunları söylemektedir:

"Yalancı eşdeğerlik, birbiri ile ilişki halinde olan ve kelime ödünçlemesi yapan bütün dünya dilleri arasında görülebilir. Çünkü sosyolojik bir varlık olarak nitelendirilebilecek bütün dillerde, tarihi akuş içerisinde kelimeler çok çeşitli sebeplerle anlam değişmesine uğrayabilirler. Yalancı eşdeğerlilik de semantik bir kavram olup anlam ve kullanım bağlamı alanındaki değişiklikte kendini göstermektedir" (Başar ve Çoşgun, 2015:501).

Bu bağlamda dünyanın en kadim dillerinden biri olan ve günümüzde çok geniş bir coğrafyada yaklaşık üç yüz milyon kişi tarafından kullanılmakta olan Türkçe de Türklerin tarih boyunca çok geniş bir coğrafyada yaşaması, dünyanın değişik coğrafyalarında onlarca devlet kurması, yaptıklarıyla tarihin akışına yön verip çağ açıp, çağ kapatması gibi sebeplerle dünya dilleriyle etkileşim içerisinde olmuş, kelime alışverişinde bulunmuş ve bu dillerle arasında yalancı eşdeğerler oluşturmuştur. Karaağaç (2015:129), konuyla alakalı bir çalışmasında Türkçenin tarihsel süreç içerisinde etkileşim içinde olduğu, kelime verdiği dilleri ve bu kelimelerin sayılarını şöyle sıralamıştır: 
Tablo 1. Karaağaç’a (2015: 129) Göre Türkçeden Diğer Dillere Geçen Sözcüklerin Dağılımı

\begin{tabular}{|c|c|}
\hline Diller & Sözcük Sayıs1 \\
\hline Bulgarca & 3995 \\
\hline Ermenice & 3166 \\
\hline Sirp- Hirvat & 3065 \\
\hline Yunanca & 2644 \\
\hline Arnavutça & 2413 \\
\hline Arapça & 1802 \\
\hline Makedonca & 1749 \\
\hline Farsça & 1696 \\
\hline Romence & 1548 \\
\hline Rusça & 1468 \\
\hline Macarca & 1143 \\
\hline İngilizce & 254 \\
\hline Urduca & 232 \\
\hline Çince & 218 \\
\hline İtalyanca & 188 \\
\hline Çekçe & 185 \\
\hline Almanca & 136 \\
\hline Fince & 113 \\
\hline $\begin{array}{l}\text { İspanyolca } \\
\text { Ispan }\end{array}$ & 85 \\
\hline Fransizca & 73 \\
\hline Portekizce & 34 \\
\hline Latince & 4 \\
\hline
\end{tabular}

Durmuş (2004) ise Türk Dil Kurumu tarafindan yayımlanan “Türkçe Sözlük” ün 9. baskısı üzerinde yaptığı bir incelemede, Türkçe Sözlükteki 60152 madde başı kelimeden 14264'ünün başka dillerden alındığını belirtmekte ve bu sözcüklerin alındığı dillere göre dağılımını şöyle göstermektedir: 
Tablo 2. Durmuş'a (2004: 19) Göre Diğer Dillerden Türkçeye Geçen Sözcüklerin Dağıllımı

\begin{tabular}{|l|l|l|l|}
\hline \multicolumn{4}{|c|}{ Türkçe Sözlük } \\
\hline Arapça & $6426: \% 10.68$ & Slavca & 17 \\
\hline Fransızca & $4645: \% 7.72$ & Moğolca & 15 \\
\hline Farsça & $1363: \% 2.26$ & Ermenice & 14 \\
\hline İtalyanca & $622: \% 1.03$ & Bulgarca & 8 \\
\hline İngilizce & 446 & İbranice & 8 \\
\hline Yunanca & 383 & Portekizce & 3 \\
\hline Latince & 93 & Japonca & 2 \\
\hline Almanca & 84 & Arnavutça & 1 \\
\hline Rusça & 38 & Norveç & 1 \\
\hline İspanyolca & 37 & Osmanlıca & 40 \\
\hline Macarca & 18 & Türkçe & 45888 \\
\hline Toplam: 60152 Kelime & \multicolumn{2}{|c|}{ Alıntı Sözcük Oran1: \% 23.72 } \\
\hline
\end{tabular}

Yukarıdaki tablolardan da görüldüğü gibi Türkçenin tarihsel süreçte en yoğun etkileşim içinde olduğu dillerden biri de Arapçadır. Türkler ve Araplar yüzyıllar boyunca aynı coğrafyada yaşamış, yakın ilişkiler içerisinde olmuş ve birbirlerini kültürel ve dilsel anlamda etkilemişlerdir Türkçe ve Arapça arasındaki etkileşim, 751 yılındaki Talas Savaşı'ndan sonra Türklerin İslamiyet ile tanışması ve kitleler halinde İslam'ı tercih etmesiyle başlamış, Selçuklu ve Osmanlı Devletleri döneminde etkisini artırarak devam etmiş ve günümüze kadar sürmüştür. Korkmaz (2007) ise konuyla alakalı bir çalışmasında bu hususta şunları söylemektedir:

“Asya ve Afrika'daki birçok millet gibi Türkler ve Araplar da uzun yıllar aynı coğrafya ve aynı ortak vatan içerisinde birlikte yaşayarak birbirlerinin dil ve kültürlerini etkilemişlerdir. Birbirlerinden kız alıp vererek aralarında akrabalık bağları kurdukları gibi dillerinden de kelimeler alıp vererek telaffuzları aynı olan yüzlerce ortak kelimeleri oluşmuştur. Telaffuzları aynı olan bu ortak kelimelerin bir kısmına yüklenen anlamlar, her iki dilde aynen korunurken diğer bazılarında ise söylenişleri aynı kalmakla birlikte (Türkçe ve Arapça arasında) birbirinden farklılaşan anlamlar yüklendiğine ve yalancı eşdeğerler oluşturulduğuna tanık olunmuştur. Örneğin iki dildeki ortak kelimelerden olan hala (Türkçe anlamı: babanın kız kardeşi, Arapça anlamı: annenin kız kardeşi), fakat (Türkçe anlamı: ama, Arapça anlamı: sadece), fen (Türkçe anlamı: Fizik, kimya, matematik ve biyolojiye verilen ortak ad, Arapça anlamı: sanat), Ustura (Türkçe anlamı: jilet, Arapça anlamı: efsane), sünnet (Türkçe anlamı: Hz. Muhammed'in Müslümanlarca uyulması gerekli sayllan davranışlarl ve herhangi bir konuda söylemiş olduğu söz, Arapça anlamı: gelenek, adet), nar (Türkçe anlamı: bir meyve, Arapça anlamı: ateş) vb. birçok kelimede bu durumla karşılaşılmaktadır." (Korkmaz, 2007:1064). 
Türkler ve Araplar arasında tarih boyunca süregelen bu ilişki sadece kelime alışverişiyle sınırlı kalmamış, aynı medeniyet dairesinde yer alan ve tarihi süreçte uzunca bir süre kader birliği yapan bu iki millet aynı zamanda birbirlerinin dillerini de öğrenmek istemişlerdir. Türkler, İslam dininin kutsal kitabı olan Kur'an'1 ve bu dine ait bilgileri daha iyi anlayabilmek gibi amaçlarla Arapça öğrenmek isterken Araplar ise İslam dünyasındaki etkinliğini giderek artıran ve İslam âleminin hamiliğini üstlenen Türklerin dilini öğrenmek istemişlerdir. Arapların Türkçe öğrenme noktasındaki artan ilgi ve taleplerini karşılayabilmek adına tarih boyunca başta Divânu Lugâti’t Türk olmak üzere Et-Tuhfetü'z-Zekiyye FilLûgati't-Türkiyye, El-Kavânînü'l-KülliyyeLi-Zabti'l-Lügati’t-Türkiyye, Kitāb-1 Mecmū'ı Tercümān-1 Türkî ve 'Acemị ve Mugalî̀' gibi çok sayıda eser kaleme alınmıştır.

Bununla birlikte Türkiye'nin son dönemde dünya siyasetinde etkinliğini arttırması, Türkiye'nin Arap ülkeleri için eğitim, turizm ve ekonomi gibi çeşitli sahalarda cazibe merkezi haline gelmesi, Türk dizilerinin Arap dünyasında oldukça rağbet görmesi ve Suriye'de yaşanan iç karışıklıklar ve savaş neticesinde sayısı 3,5 milyonu bulan Suriyeli mültecinin ülkemize sığınması gibi sebeplerin Türkçenin yabancı dil olarak öğretimine yeni bir boyut getirdiği ve bu kapsamda Araplara Türkçe öğretimi konusunun daha da önem kazandığı söylenebilir.

Bilindiği üzere yabancı dil öğretimi oldukça uzun ve zor bir süreçtir. Bu süreçten beklenen verimin alınabilmesi için öğrenenlerin zihinsel, gelişimsel, rrksal ve dilsel ( ana dili, ana dilinin yapısı, hedef dil ile kaynak dilin benzeyen ve benzemeyen yönleri vb.) özelliklerinin göz önünde bulundurularak sürecin en ince ayrıntısına kadar planlanması ve çağdaş dil öğretim yöntem ve ilkelerine uygun olarak yürütülmesi gereklidir.

Bu kapsamda ana dili Arapça olan öğrencilere Türkçenin yabancı dil olarak öğretimi sürecinde dikkat edilmesi gereken en önemli hususların başında hiç kuşkusuz bu dillerin söz varlıkları gelmektedir. Zira bahsi geçen bu diller tarihsel süreçte çok yoğun bir etkileşim içinde olmuş ve sayısı on binlerle ifade edilebilecek düzeyde ortak kelime havuzu oluşturmuşlardır. İki dil arasındaki ortak kelimelerin çokluğu, Türkçe öğrenmek isteyen ve ana dili Arapça olan öğrenenlerin işini kolaylaştırmakla birlikte çeşitli sorunlara da neden olmaktadır. Zira bu kelimelerden bir kısmı zaman içerisinde çeşitli sebeplerle anlam değişimine uğrayarak iki dil arasında yazılışları ve okunuşları aynı, anlamları farklı yalancı eşdeğerlikler oluşturmuştur. Bu türden kelimeler, ana dili Arapça olanlara yabancı dil olarak Türkçe öğretimi sürecinde önemli bir sorun oluşturmaktadır. Zira Yakıcı vd.'nin (2010) de ifade ettiği gibi hiçbir insan ana dilini kazandıktan sonra bu dilden kurtulamaz. Sonraki dilleri de ana dilinin üzerinden öğrenir. Benzer bir şekilde Türk gramerciliğinin öncülerinden biri olarak kabul edilen Bergamalı Kadri tarafindan 1530 yılında kaleme alınan "Müyessiretü'l-Ulûm” adlı eserde Ertürk'ün (2015:1084) aktardığ "Her tâife kendü lügâtı kâidesin tiz anlar; sonra sâir lügâtleri kendü lügâtine kıyâs idüp sehl zamânda çok iz'âna yitişür" şeklindeki ifade Bergamalı Kadri'ye göre de yabancı dil öğrenme sürecinin ana dili üzerine inşa edildiğini göstermektedir. Nitekim ana dili Arapça olan öğrenenler de bu türden 
kelimelerle karşılaştıklarında kelimeleri Arapçadaki anlam ve bağlamında kullanma eğilimi göstermekte, yazılı ve sözlü anlatımda ciddi hatalar yapmaktadırlar.

$\mathrm{Bu}$ durumun olumsuz sonuçlarının önüne geçilebilmesi ve yabancılara Türkçe öğretimi sürecinden beklenen verimin elde edilebilmesi için sürecin başında öğrenim gören hedef kitlenin ana dili ile Türkçe arasındaki yalancı eşdeğer kelimeler bilinmeli ve süreç bu doğrultuda planlanmalıdır. Başar ve Coşgun'un (2015) da belirttikleri gibi yabanc1lara Türkçe öğretimi sürecinde görev alan eğitimcilerin yalancı eşdeğere sahip kelimeleri önceden bilmesi, öğreticiye hedef kitlenin yapabileceği hataları tahmin etme ve bu doğrultuda önlem alma olanağı sunacaktır.

Bununla birlikte ilgili alan yazın incelendiğinde yalancı eşdeğer kelimeler ile ilgili çalışmaların daha çok Türkiye Türkçesi ile diğer Türk lehçeleri arasındaki yalancı eşdeğer kelimelerin tespiti ile sınırlandırıldığı, diğer dillerle Türkçe arasındaki yalancı eşdeğer kelimelerin ve bu kelimelerin Türkçenin yabancı dil olarak öğretimi sürecine etkisinin ihmal edildiği görülmektedir.

Bu doğrultuda bu çalışmanın amacı, Türkçe ile Arapça arasındaki yalancı eşdeğer kelimelerin, ana dili Arapça olan öğrencilere Türkçenin yabancı dil olarak öğretimi sürecine etkilerini belirlemek ve bu alanda çalışmak isteyen araştırmacıların hizmetine sunmaktır.

\section{Yöntem}

$\mathrm{Bu}$ bölümde araştırmanın modeline, çalışma grubuna, veri toplama ve veri analiz yöntemine ilişkin açıklamalara yer verilmiştir.

\subsection{Araștırmanın Modeli}

Yalancı eşdeğer kelimelerin, ana dili Arapça olan öğrencilere yabancı dil olarak Türkçe öğretimi sürecine etkilerini belirlemeyi amaçlayan bu çalışma nitel araştırma yöntemine göre düzenlenmiştir. "Nitel araştırma, gözlem, görüşme ve doküman analizi gibi nitel veri toplama yöntemlerinin kullanıldığ1, olguların ve olayların doğal ortamda gerçekçi ve bütüncül bir biçimde ortaya konmasına yönelik nitel bir sürecin izlendiği araştırma olarak tanımlanabilir" (Yıldırım ve Şimşek, 2008:39). Bu doğrultuda nitel veri toplama tekniklerinden yapılandırılmış görüşme kullanılmıştır.

\section{2. Çalışma Grubu}

Araştırmanın çalışma grubunu, Van YYÜ TÖMER'de yabancı dil olarak Türkçe öğrenen, ana dili Arapça olan ya da ülkesinde resmi dil olarak Arapça kullanılan, B1-B2 düzeyindeki yabancı uyruklu 14 öğrenci oluşturmaktadır.

Araştırmanın çalışma grubuna dâhil edilen öğrencilerin görüşme formlarında yer alan sorulara verdikleri cevaplar doğrultusunda sahip oldukları demografik özelliklerin dağılımı şu şekildedir. 
Tablo 3. Öğrencilerin Cinsiyet Dă̆glımı

\begin{tabular}{lll}
\hline Cinsiyet & f & $\%$ \\
\hline Kadın & 8 & 57.14 \\
\hline Erkek & 6 & 42.86 \\
\hline Toplam & 14 & 100 \\
\hline
\end{tabular}

Tablo 3'te çalışma grubunda yer alan öğrencilerin cinsiyet dağılımı verilmiştir. Bu dağılıma göre öğrencilerin 8'i (\%57.14) kadın, 6’sı (\%42.86) ise erkektir. Bu durum çalışma grubunda yer alan öğrencilerin cinsiyet açısından dengeli bir dağılıma sahip olduğunu göstermektedir.

Tablo 4. Öğrencilerin Yaş Dă̆glımları

\begin{tabular}{lll}
\hline Yaş Aralı̆̆ı & f & $\%$ \\
\hline 20 ve Aşă̆ı & 9 & 64.29 \\
\hline $21-25$ & 3 & 21.43 \\
\hline $26-30$ & 2 & 14.28 \\
\hline Toplam & 14 & 100 \\
\hline
\end{tabular}

Tablo 4'e göre çalışma grubundaki öğrencilerin 9’u (\%64.29) 20 ve aşağı, 3’ü (\%21.43) 21-25, 2'si (\%14.28) ise 26-30 yaş grubuna dâhildir.

Tablo 5. Öğrencilerin Ĕ̆itim Durumu

\begin{tabular}{lll}
\hline Eğitim & f & $\%$ \\
\hline Lise & 2 & 14.28 \\
\hline Lisans & 11 & 78.58 \\
\hline Lisansüstü & 1 & 7.14 \\
\hline Toplam & 14 & 100 \\
\hline
\end{tabular}

Tablo 5'te öğrencilerin eğitim durumlarına ilişkin bilgilere yer verilmiştir. Bu dağılama göre öğrencilerin büyük çoğunluğu (\%78.58) lisans mezunu ya da lisans eğitimine devam eder durumdadır.

Tablo 6. Ö̆̆rencilerin Türkçe Ö̆̆renme Süresi

\begin{tabular}{lll}
\hline Süre & f & $\%$ \\
\hline $0-6$ ay & 6 & 42.85 \\
\hline 6-12 ay & 8 & 57.15 \\
\hline Toplam & 14 & 100 \\
\hline
\end{tabular}

Tablo 6'ya göre öğrencilerden 6'sı (\%42.85) 0-6 ay, 8'i (\%57.15) ise 6-12 aydır yabancı dil olarak Türkçe öğrenmektedir. 
Tablo 7. Öğrencilerin Türkiye'de Bulunma Süresi

\begin{tabular}{lll}
\hline Süre & f & $\%$ \\
\hline $0-6$ ay & 8 & 57.15 \\
\hline $6-12$ ay & 4 & 28.57 \\
\hline $12-24$ ay & 2 & 14.28 \\
\hline Toplam & 14 & 100
\end{tabular}

Tablo 7'de çalışma grubunda bulunan öğrencilerin Türkiye'de yaşama sürelerine ilişkin bilgilere yer verilmiştir. Tablo 5'e göre öğrencilerden "Ne kadar süredir Türkiye'desiniz?” sorusuna 06 ay olarak cevap verenler 8 (\% 57.15), 6-12 ay olarak cevap verenler 4 (\% 28.57), 12-24 ay olarak cevap verenler ise $2(\% 14.28)$ kişidir.

Tablo 8. Öğrencilerin Türkiye’ye Gelmeden Önce Türkçe Öğrenme Girişimleri

\begin{tabular}{lll}
\hline Girişim Durumu & f & $\%$ \\
\hline Evet & 4 & 28.57 \\
\hline Hayır & 10 & 71.43 \\
\hline Toplam & 14 & 100
\end{tabular}

Tablo 8'e göre çalışma grubunda yer alan yabancı uyruklu öğrencilerden 4'ü ( \% 28.57) Türkiye'ye gelmeden önce Türkçe öğrenmeye başladığını ifade ederken 10'u (\%71.43) ise bu konuda herhangi bir girişimde bulunmadığını belirtmiştir.

Tablo 9. Öğrencilerin Ülkelere Göre Dă̆ılımı

\begin{tabular}{lll}
\hline Ülke & f & $\%$ \\
\hline Suriye & 6 & 42.85 \\
\hline Ürdün & 4 & 28.57 \\
\hline Irak & 3 & 21.42 \\
\hline Mısır & 1 & 7.14 \\
\hline Toplam & 4 & 100
\end{tabular}

Tablo 9'da çalışma grubundaki öğrencilerin geldikleri ülkelere göre dağglımına ilişkin bilgilere yer verilmiştir. Tablodaki dağılıma göre öğrencilerin büyük çoğunluğu $(\% 42.85)$ Suriye'den gelmiştir. 


\subsection{Verilerin Toplanması}

$\mathrm{Bu}$ çalışmada, veri toplama sürecinde araştırmacılar tarafından geliştirilen yapılandırılmış görüşme formları kullanılmıştır.

Bu kapsamda öncelikle yalancı eşdeğer kelimelerin ana dili Arapça olan öğrencilere yabancı dil olarak Türkçe öğretimi sürecine etkilerine ilişkin görüşlerini alabilmek için yabancı dil olarak Türkçe öğrenen ve ana dili Arapça olan öğrenciler için yapılandırılmış görüşme formları hazırlanmıştır. Görüşme formları hazırlanırken Türkçe eğitimi alanında görev yapan iki uzmanın görüşüne başvurulmuş ve uzman görüşleri doğrultusunda formlarda gerekli değişiklikler yapılmıştır. Son hali verilen formlar katılımcılara yazılı olarak uygulanmış ve elde edilen bilgilerin sadece bilimsel amaçla kullanılacağı, kişisel bilgilerin üçüncü kişilerle paylaşılmayacağı katılımcılara bildirilmiştir.

Görüşme formları ikişer bölümden oluşmaktadır. Öğreniciler için hazırlanan görüşme formunda toplam 16 soru bulunmaktadır. Formların birinci bölümünde katılımcıların demografik özelliklerini ve akademik durumlarını belirlemeye yönelik sorulara yer verilmiş, ikinci bölümlerinde ise katılımcıların, yalancı eşdeğer kelimelerin Türkçe öğrenimi ve öğretimine etkisine ilişkin görüşlerini almaya yönelik sorulara yer verilmiştir.

\subsection{Verilerin Analizi}

Araştırmada kapsamında toplanan veriler içerik analizi aracılığıyla çözümlenmiştir. "İçerik analizinde temel amaç, toplanan verileri açıklayabilecek kavramlara ve ilişkilere ulaşmaktır. İçerik analizinde temelde yapılan işlem, birbirine benzeyen verileri belirli kavramlar ve temalar çerçevesinde bir araya getirmek ve bunları okuyucunun anlayabileceği bir biçimde düzenleyerek yorumlamaktır.” (Yıldırım ve Şimşek, 2008:227). Bu kapsamda araştırmanın verilerini oluşturan görüşme formlarındaki sorulara verilen cevaplardan hareketle Türkçe ve Arapça arasındaki yalancı eşdeğer kelimelerin ana dili Arapça olan öğrencilere yabancı dil olarak Türkçe öğretimi sürecine etkileri tespit edilmeye çalışılımıştır.

\section{Bulgular}

Çalışmamızın bu bölümünde çalışma kapsamında elde edilen bulgular tablolar halinde sunulmuş ve tablo yorumlamalarına yer verilmiştir. 
Tablo 10. Íki Dilde Çok Sayıda Ortak Kelime Olmasının Türkçe Öğrenimine Etkisi

\begin{tabular}{lll}
\hline Etkisi & f & $\%$ \\
\hline Türkçe öğrenmemizi kolaylaştırıyor & 9 & 64.28 \\
\hline Türkçeyi daha hızlı öğrenmemize olanak sağlıyor & 2 & 14.28 \\
\hline Etkilemiyor & 1 & 7.14 \\
\hline Boş & 2 & 14.28 \\
\hline Toplam & 14 & 100 \\
\hline
\end{tabular}

Tablo 10'da çalışma grubunda yer alan öğrencilerden “ Ana diliniz ve Türkçede çok sayıda ortak kelime bulunması Türkçe öğrenme sürecinizi nasıl etkiliyor?" sorusunu "Türkçe öğrenmemizi kolaylaştırıyor.” olarak cevaplayanlar 9 (\%64.28), “ Türkçeyi daha hızlı öğrenmemize olanak sağlıyor.” olarak cevaplayanlar 2 (\%14.28), "Etkilemiyor." olarak cevaplayanlar ise 1 ( \% 7.14) kişidir. Öğrencilerden 2'si (\%14.28) ise bu soruya herhangi bir cevap vermemiştir.

Tablo 11. Yalancı Eşdeğer Kelimelerin Türkçe Öğrenim Sürecine Etkisi ve Dağılımları

\begin{tabular}{|c|c|c|c|c|}
\hline Durum & $\mathbf{f}$ & $\%$ & Etkinin Dağılı & \\
\hline Etkiliyor & 9 & 64.28 & \multirow{4}{*}{\multicolumn{2}{|c|}{ 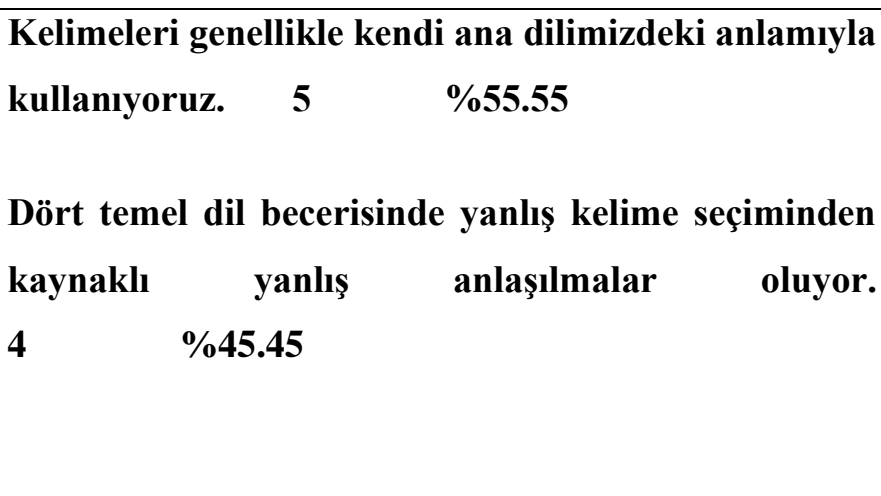 }} \\
\hline Etkilemiyor & 2 & 14.28 & & \\
\hline Boş & 3 & 21.44 & & \\
\hline Toplam & 14 & 100 & & \\
\hline
\end{tabular}

Tablo 11'e göre yalancı eşdeğer kelimelerin Türkçe öğrenme sürecine etkisi olduğunu düşünen 9 (\% 64.28) öğrenciden 5'i (\%55.55) bu durumun "kelimelerin genellikle kendi ana dillerindeki anlamıyla kullanılmasına", 4’ü (\%45.55) ise "dört temel dil becerisinde yanlış kelime seçiminden kaynaklanan yanlış anlaşılmalara" sebep olduğunu düşünmektedir. 
Tablo 12. Yalancı Eşdeğer Kelimelerin Öğretim Elamanları Tarafindan Dikkate Alınma Durumları ve Dikkate Alınmasının Sağladığı Kolaylıklar

\begin{tabular}{|c|c|c|c|c|c|}
\hline Durum & f & $\%$ & \multicolumn{3}{|c|}{ Dikkate Alınmasının Sağladığı Kolaylıklar } \\
\hline Evet & 9 & 64.28 & Türkçeyi daha kolay öğrenme & 4 & $\% 44.45$ \\
\hline Hayır & 4 & 28.57 & \multirow{3}{*}{ Türkçeyi daha çabuk öğrenme } & & \\
\hline Boş & 1 & 7.14 & & 3 & $\% 33.33$ \\
\hline Toplam & 14 & 100 & & 2 & $\% 22.22$ \\
\hline
\end{tabular}

Tablo 12'de “Türkçe öğretimi sürecinde yalancı eşdeğer kelimeler öğretim elemanları tarafindan dikkate alınıyor mu?” sorusunu evet olarak cevaplayan 9 (\%64.28) öğrenciden 4’ü (\%44.45) bu durumun "Türkçeyi daha kolay öğrenmelerine”, 3’ü (\%33.33) “Türkçeyi daha çabuk öğrenmelerine” olanak sağladığını ifade etmiştir. Öğrencilerden 2'si (\%22.22) ise bu konuda bir görüş belirtmemiştir.

Tablo 13. Konuşmada Yalancı Eşdeğer Kelimelerden Kaynaklanan Sorunlar ve Sorunların Dağılımı

\begin{tabular}{|c|c|c|c|c|c|}
\hline Durum & $\mathbf{f}$ & $\%$ & Yaşanan Sorunların Dağıl & Imı & \\
\hline Yaşıyorum & 8 & 57.14 & \multirow{4}{*}{\multicolumn{2}{|c|}{ Yanlış anlatma- Yanlış anlaşılma 3}} & $\% 62.5$ \\
\hline Yaşamıyorum & 4 & 28.57 & & & \multirow{3}{*}{$\% 37.5$} \\
\hline Boş & 2 & 14.28 & & & \\
\hline Toplam & 14 & 100 & & & \\
\hline
\end{tabular}

Tablo 13’te çalışma grubundaki yabancı uyruklu öğrencilerin Türkçe öğrenme sürecindeki yalancı eşdeğer kelimelerden kaynaklanana sorunlar ve bu sorunların dağılımına ilişkin bilgilere yer verilmiştir. Bu dağılıma göre öğrencilerin büyük çoğunluğu (\%57.14) konuşmada yalancı eşdeğer kelimelerden kaynaklanan bazı sorunlar yaşadığını belirtmiştir. Bu öğrencilerden 5’i (\%62.5) “ yanlış kelime seçimi”, 3’ü (\%37.5) ise “ yanlış anlatma- yanlış anlaşılma” gibi sorunlarla karşı karşıya olduklarını ifade etmiştir. 
Tablo 14. Yazmada Yalancı Eşdeğer Kelimelerden Kaynaklanan Sorunlar ve Sorunların Dağılımı

\begin{tabular}{|c|c|c|c|c|}
\hline Durum & f & \multicolumn{3}{|c|}{ Yaşanan Sorunların Dağılımı } \\
\hline Yaşıyorum & 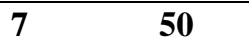 & \multicolumn{3}{|c|}{ Kendini ifade edememek ya da } \\
\hline Yaşamıyorum & 4 & yanlış ifade etmek & 4 & $\% 57.14$ \\
\hline Boş & 21.43 & Yanlış kelime seçimi & 2 & $\% 28.57$ \\
\hline Toplam & 14 & Boș & 1 & $\% 14.28$ \\
\hline
\end{tabular}

Tablo 14'e göre "Yazmada yalancı eşdeğer kelimelerden kaynaklanan sorunlar yaşıyor musunuz?" sorusuna evet olarak cevap veren 7 (\%50) öğrenciden 4'ü (\%57.14) bu durumun "Kendini ifade edememek ya da yanlış ifade etmek", 2'si (\%28.57) “yanlış kelime seçimi”" gibi çeşitli sorunlara sebep olduğunu belirtmiştir.

\section{Sonuç ve Tartışma}

Türkçe ile Arapça arasındaki yalancı eşdeğer kelimelerin yabancılara Türkçe öğretimindeki etkilerini belirlemeyi amaçlayan bu çalışma kapsamında toplanan veriler değerlendirilerek çalışmanın bulguları elde edilmiş, bu bulgulardan hareketle ise şu sonuçlara ulaşılmıştır:

Araştırmamızın çalışma grubunda yer alan öğrencilerden \%64. 2'si Türkçe ve Arapçada çok sayıda ortak kelime olmasının Türkçe öğrenimini kolaylaştırdığını, \%14.28’i bu durumun Türkçeyi daha çabuk öğrenmelerine olanak sağladığını belirtirken \%7.14'lük kısmı ise bu durumun Türkçe öğrenme sürecinde herhangi bir etkisi olmadığını ifade etmiştir. Bu dağılımdan da açıkça görüldügü gibi öğrencilerin büyük çoğunluğu iki dil arasında çok sayıda ortak kelime olmasının Türkçe öğrenme süreçlerine olumlu yansıdığını düşünmektedir. İlgili alan yazın incelendiğinde çalışmamızla benzer sonuçlara ulaşılan bazı çalışmaların olduğu görülmüştür. Bunlardan Ambrozova (2014), farklı dillerde aynı kökten gelen veya ortak eşdeğerlerden kaynaklanan kelimelerin iletişimde ve hedef dilin öğrenilmesinde büyük kolaylıklar sağladığını ifade etmiş̧tir. Benzer bir şekilde Yurtbaşı (2018) da bu kelimelerin yabancı dil öğrenenler için can simidi gibi olduğunu ve Türkçe öğrenmek isteyen Arapların ya da Arapça öğrenmek isteyen Türklerin, bu iki dilde çok sayıda ortak kelime olması sayesinde dil öğrenme sürecinde olumlu tutumlar geliştirdiğini ve birçok açıdan rahatladığını belirtmiştir.

Yabancı dil öğreniminde öğrenenin ana dili ile hedef dil arasındaki ortak kelimelerin çokluğu öğrenme sürecine olumlu yansımakla birlikte bazı sorunlara da neden olabilmektedir. Bu sorunların en önemlilerinden biri de bu kelimelerin zaman içerisinde çeşitli sebeplerle anlam değişmesine uğrayarak iki dilde farklı anlam yapılarını karşılayan yalancı eşdeğerler oluşturmasıdır. Nitekim çalışma 
grubumuzdaki yabancı uyruklu öğrencilerin \% 64.28'i de bu konuda bu doğrultuda düşünmekte ve bu kelimelerin Türkçe öğrenme sürecinde bazı sorunlara neden olduğunu belirtmektedir. Aboux (2003) da yalancı eşdeğerlerin yabancı dil öğretiminin en aldatıcı unsurları olduğunu ifade etmiştir.

Türkçe öğrenen ve ana dili Arapça olan öğrencilerin yalancı eşdeğer kelimelerden dolay1 yaşadığı sorunların başında, kelimeleri kendi ana dillerindeki anlamlarında kullanmak ve buna bağlı olarak dört temel dil becerisinde yaşanan yanlış anlaşılmalar gelmektedir. Nitekim Başar ve Coşgun (2015) da konuyla alakalı bir çalışmalarında hedef kitlenin bu tür kelimeleri daha çok ana dillerindeki mana ve bağlamında kullanma eğiliminde olduğunu ve bu durumun hedef kitlenin yazılı ve sözlü anlatımlarında sık sık hata yapmalarına yol açtığını ifade etmiştir. Arslan (2015) ise konuyla alakalı bir çalışmasında bu hususa dikkat çekmiş ve şunları söylemiştir:

"Yabancı dil öğrenmeye başlayan bir kişinin kelime hazinesi ve dil duygusu sinırlıdır. Bu nedenle söz konusu kişi, yabancı dilde yapı ve fonetik olarak kendi dilindekine benzer kelimeleri, ana dilindeki gönderge ve anlamıyla değerlendirme eğilimindedir. Bu açıdan ana dil ve yabancı dil arasında yapı itibarılla benzer kelimelerin anlam alanlarının da birbiriyle örtüşmesi, iletişsime olumlu bir katkı sağlayacağı ve dil öğrenimini kolaylaştıracağl gibi, anlam alanlarının farklılık göstermesi, girişim hatalarını artırı"” (Arslan, 2015:57).

Araştırmamızın çalışma grubundaki öğrencilerin çoğunluğu (\%64.28) yalancı eşdeğer kelimelerin Türkçe öğrenme süreçlerinde öğretim elamanları tarafından dikkate alındığını, \%28.57’lik kısmı ise bu konunun öğretim elamanları tarafından dikkate alınmadığını ifade etmiştir. Bu durum hem çağdaş yabancı dil öğretim ilkelerine hem de öğrenme sürecinin öznesi ve merkezi durumundaki öğrencilerin beklentisine uygundur. Zira daha önce de ifade edildiği gibi çalışma grubundaki öğrencilerin büyük çoğunluğu yalancı eşdeğer kelimelerin Türkçe öğrenme sürecinde etkili olduğunu ve dikkate alınması gerektiğini belirtmiştir. Aynı şekilde Korkmaz (2018: 98) da dil öğretiminde en önemli şeyin hedef kitleyle doğru iletişim kurmak olduğunu, ilk aşamada öğretmenin öğrencideki ana dil mantığını anlaması gerektiğini ve öğretim sürecinde iki dilde bulunan ortak kelimelere özellikle de anlam değişmesine uğrayan yalancı eşdeğer kelimelere dikkat etmesi gerektiğini aksi takdirde ortak olduğu düşünülen bu kelimelerin ciddi yanlış anlamalara yol açabileceğini ifade etmiştir.

Çalışma grubumuzdaki öğrencilerin \%57.14'ü Türkçe öğrenme sürecinde konuşma becerisinde yalancı eşdeğer kelimelerden kaynaklanan bazı sorunlar yaşadığını ve bu durumun yanlış kelime seçimi ve bunun akabinde yanlış anlatma- anlaşılmayla neticelendiğini ifade etmiştir. Nitekim Arslan (2015) da iki dilde yapının uyuştuğu ancak anlam olarak birbirinden ayrılan kelimelerin yani yalancı eşdeğerlerin girişim hatalarına neden olduğunu ve iletişimi zorlaştırdığını belirtmiştir.

Konuşma becerisinde olduğu gibi yazma becerisinde de çalışma grubuna dâhil edilen yabanc1 uyruklu öğrencilerin çoğunluğu yalancı eşdeğer kelimelerden kaynaklanan birtakım sorunlar yaşadığını belirtmiştir. Bu sorunların başında kelimeleri kendi ana dillerindeki anlamıyla düşünmeleri ve bunun 
neticesinde yazılı anlatımda yanlış kelime seçimi gelmektedir. Başar ve Coşgun (2015) da konuyla alakalı yapmış oldukları bir çalışmalarında bu noktaya dikkat çekmiş ve öğrencilerin yazılı anlatımlarındaki yalancı eşdeğer kelimelerden kaynaklanan hatalı kullanımları örneklendirmişlerdir. Benzer bir şekilde Özden, Boylu ve Başar (2017) da yabancılara Türkçe öğretimi sürecinde yalancı eşdeğer kelimelerin göz ardı edilmesinin anlatım bozukluklarına sebep olduğunu belirtmişlerdir.

Çalışmamız kapsamında elde edilen bulgular ve ulaşılan sonuçlardan hareketle Ana dili Arapça olan öğrencilere yabancı dil olarak Türkçe öğretiminde yalancı eşdeğer kelimelerden kaynaklanan hataların en aza indirgenmesine yönelik belirlenen öneriler şunlardır:

1. İlgili alan yazında da ifade edildiği gibi bir dili bilmek ile o dili öğretmek aynı şeyler değildir. $\mathrm{Bu}$ nedenle alanda görevlendirilecek öğretim elamanları çağdaş dil öğretim yöntemlerine vâkıf olan, hedef dilin olduğu kadar öğrenenin ana dilinin de inceliklerine hâkim uzmanlar arasından seçilmelidir.

2. Yabancılara Türkçe öğretimi sürecinde öğrenenin ana dili uzak durulması, kaçınılması ya da yasaklanması gereken değil aksine faydalanılması gereken bir olgudur. Öğretim elamanları iki dilin benzerlik ve farklıl1klarının bilincinde olmalı ve bunlardan faydalanma yoluna gitmelidir.

3. Hiç şüphesiz yabancı dil öğretiminin en önemli aşamalarından biri de kelime öğretimidir. $\mathrm{Bu}$ sürece kaynak dil ile hedef dildeki eşdeğer kelimelerden başlanılması dil öğretim sürecini kolaylaştıracağı gibi öğrenenlerin de dil öğrenme sürecine ilişkin olumlu tutumlar geliştirmesine katkıda bulunacaktır.

4. Yabancılara Türkçe öğretimi sürecinde kaynak dil ile hedef dil arasındaki eşdeğer kelimeler kadar yalancı eşdeğer kelimeler de hesaba katılmalı ve önceden hazırlanan yalancı eşdeğer kelimeler listesi dil öğretim sürecinin başında öğrencilerin ve öğretim elamanların istifadesine sunulmalıdır. Zira bu türden kelimeler, öğrenme-öğretme sürecinin başında öğrenici ve öğretici tarafından bilinirse öğrenenin ana dilinden yapacağı olumsuz aktarımların önüne geçilebilir ve Türkçe öğretim sürecinden beklenen verim elde edilebilir.

5.Yabancılara Türkçe öğretimi, uygulamadakinin aksine homojen sınıflarda yapılmalı ve hem öğrenme süreci hem de kullanılan yöntem, teknik, araç-gereç ve materyaller dil öğrenme sürecinin öznesi ve merkezi konumunda olan öğrenenin özelliklerine göre planlanmalıdır.

6.Öğretim elamanları, dil öğretim sürecinde öğrenenler tarafindan yapılan yalancı eşdeğer kelimelerden kaynaklanan hataları olağan karşılamalı, hoşgörüyle yaklaşmalı ve yapılan hataları zaman kaybetmeden uygun bir dille düzeltmelidir.

7. Daha önce Robert J. Hill'in hazırlamış olduğu ve İngilizce ile 14 farklı dil arasındaki yalancı eşdeğer kelimeleri içeren "A Dictionary of False Friends" gibi Türkçe ile diğer dünya dilleri arasındaki yalancı eşdeğer kelimeleri içeren kapsamlı sözlükler hazırlanmalı ve bu alanda çalışan akademisyenlerin ve öğrencilerin hizmetine sunulmalıdır. 
8. Bu çalışma Ana dili Arapça olan öğrencilere yabancı dil olarak Türkçe öğretiminde yalancı eşdeğer kelimelerin etkileriyle ile sınırlandırılmıştır. Ana dili olarak başka dilleri konuşan öğrenciler için de benzer çalışmalar yapılabilir. 


\section{Kaynakça}

Aboux Khalil, Victoria (2003) "Learning False Friends Across Contexts, Graduate School of Informatics, Kyoto University Nation.", Asian EFL Journal, 5.2, ss.1-8.

Alkan, Hanife (2012) “Lehçeler Arası Aktarmada Yalancı Eş Değerler Sorunu (Türkiye Türkçesi Özbek TürkçesiYeni Uygur Türkçesi Fiil Örneği)”,TurkishStudies, 7.4, ss.671-688.

Ambrožová, Romana (2014). Between True And False Friends: Corpus Analysis of Students' Translations, University of Masarykova, Doctoral dissertation, Çek Cumhuriyeti.

Arslan, Müge (2015) “Türkçe ve Almanca Arasındaki Sözde Eş Değerler”, Journal of Faculty of Letters/Edebiyat Fakultesi Dergisi, 32.1, ss.45-58.

Başar, Umut ve Coşgun Gökhan (2015) “İranlılara Yabancı Dil Olarak Türkiye Türkçesi Öğretiminde Önemli Bir Sorun: Yalancı Eşdeğerlikler”, Uluslararası Ĕgitim Bilimleri Dergisi, C:4, ss.497-512.

Direkci, Bekir ve Gülmez Mevlüt (2012) "Güney Azerbaycan Türkçesi ve Türkiye Türkçesi Arasındaki Yalanc1 Eş Değerler”, Selçuk Üniversitesi Türkiyat Araştırmaları Dergisi, C:32, ss.133-154.

Durmuş, Oğuzhan (2004) "Alıntı Kelimeler Bakımından Türkçe Sözlük”, Atatürk Üniversitesi Türkiyat Araştırmaları Enstitüsü Dergisi, 11.26, ss.1-21.

Ertürk, Halil İbrahim (2015) “Müyessiretü’l-Ulûm Üzerine Bir İnceleme Ve Değerlendirme Çalışması”, Turkish Studies, 10.8, ss. 1059-1086.

Fromkin, Victoria, Rodman Robert ve Hyams, N. (2007). An Introduction to Language, Thomson Wadsworth, Boston.

Güngör, Okan Celal (2017) "Türkiye Türkçesi İle Yeni Uygur Türkçesinde Yalancı Eş Değerler (İsim ve İsim Soylu Kelimeler Örneği)”, Uluslararası Türkçe Edebiyat Kültür Eğitim (TEKE) Dergisi, 6.1, ss.133-171.

İnan, Kayhan (2013). Yabancı Dil Olarak Türkçe Öğrenen İranlıların Yazılı Anlatımları Üzerine Bir İnceleme, Gazi Üniversitesi Eğitim Bilimleri Enstitüsü, Yayınlanmamış Yüksek Lisans Tezi, Ankara.

Karaağaç, Günay (2015) Türkçenin Alıntılar Sözlüğü, Akçağ Yayıncılık, Ankara.

Korkmaz, Ercan (2018) "Yabancılara Türkçe Öğretiminde Yaşanan Bazı Sorunlar ve Çözüm Önerileri”, KSÜ Sosyal Bilimler Dergisi, 15.1, ss.89-105.

Korkmaz, Seyfullah (2007) “Türkçe ve Arapçada Telaffuzları Aynı, Anlamları Farklılaşmış Bazı Sözler Üzerine Bir Araştırma” [Bildiri], 38.Uluslararası Asya Ve Kuzey Afrika Çalışmaları Kongresi, 10-15 Eylül, Ankara.

Özden, Mehtap Güneş, Boylu Emrah ve Başar Umut (2017) “İran'da Yabancı Dil Olarak Türkçe Öğreten Yerel Öğretmenlerin Dil Öğretim Tecrübelerine İlişkin Bir Durum Tespiti Çalışması” Atatürk Üniversitesi Türkiyat Araştırmaları Enstitüsü Dergisi, C:59, ss.595-613.

Yakıc1, Ali, Yücel Mustafa, Doğan Mehmet ve Yelok V. Savaş (2012) Üniversiteler İçin Türk Dili ve Kompozisyon Bilgileri, Yarg1, Ankara.

Yıldırım, Ali ve Şimşek Hasan (2008) Sosyal Bilimlerde Nitel Araştırma Yöntemleri, Seçkin yayıncılık, Ankara.

Yurtbaşı, Metin (2018) “Türkçe'nin 'Yalancı Eşdeğerleri' (Faux Amıs)” Akademik Sosyal Araştırmalar Dergisi, 6.80, ss. 386-406. 